\title{
PURIFICATION AND CHARACTERIZATION OF UREA TRANSPORTER BY SDS-PAGE FROM THE PADDY GROWN IN UREA TREATED SOIL
}

\author{
M. S. Haque and M. K. Hasan \\ Department of Biochemistry and Molecular Biology, Laboratory of Protein and Enzyme \\ Research, University of Rajshahi, Rajshahi-6205, Bangladesh
}

\begin{abstract}
G-50 chromatography of extract of paddy plant induced by urea revealed the major three peaks F-1, F-2 and F-3 against the absorbance at $280 \mathrm{~nm}$ with the number of fractions. Chromatogram was also obtained from the control of extract of paddy, however, urea-induced paddy extract showed the higher absorbance than the control showing the higher protein content. F-1 fraction for both groups having the higher molecules are considered to have the urea transporter and are applied to SDS-PAGE for purification and characterization. For identification of urea transporter, a mixture of marker proteins- $\beta$-galactosidase, BSA, egg white albumin, pepsin, trypsin inhibitor and lysozyme were used. Depending on the mobility of the sample, ureatransporter had been identified as a large band having the MW of $50.6 \mathrm{kDa}$ compared to the MW of BSA. For control, SDS-PAGE shows the same band for urea-transporter but the expression was lower than the urea-treated paddy. In SDS-PAGE gel, both bands were homogenous showing the homogeneity of urea-transporter. The results demonstrate that urea application in the soil induces the expression of urea transporter which will be a new finding for the clarification of mechanism of urea transport in plants.
\end{abstract}

Key Words : Paddy extract, SDS-PAGE, Soil urea, Urea transporter

\section{INTRODUCTION}

As a potent nitrogenous nutrient for plant, urea has been considered for plant cultivation. Plants optimize and regulate nitrogen acquisition by regulated expression of specific transport proteins. Expression and activity of such transporters depend on the environment, nutrient availability, competitors, stress and metabolism. Genes encoding the representatives of two families of nitrate-induced nitrate transporters (NRTs) have been cloned (Tsay et al., 1993; Huang et al., 1996). An Nrt2 family contributes to a highly inducible, high affinity nitrate uptake system. The Nrt1 group appears to account for more general, low level nitrate uptake characterized by constitutive, although to some extent, inducible gene expression (Crawford and Glass, 1998; Lejay et al., 1990). It has been demonstrated that application of urea in the soil as well as foliar application, induces plant growth by stimulating the synthesis of enzymes and proteins (Claus-Peter et al., 2002). Urea is degraded by urease to $\mathrm{NH}_{4}{ }^{+}$and $\mathrm{CO}_{2}$ by conversion to nitrate. $\mathrm{NH}_{4}{ }^{+}$ is utilized by the plant cells for plant growth through ammonium-specific transporters (von Wiren et al., 2000). Although nitrate transporter in plants has been identified, however uptake pathways for urea transport into plant cells is poorly understood. 
Therefore, the present study has been undertaken for the identification of urea transporter with preference usage of SDS-PAGE method commonly used for checking the purity and molecular weight determination of proteins. The SDS-PAGE method had also been applied to characterize the urea transporter.

\section{MATERIALS AND METHODS}

\section{Plant materials and urea treatment}

The rice seedlings were prepared in the University Campus and grown with BRRI-27 seeds collected from the near by Bangladesh Rice Research Institute (BRRI), Sympur, Rajshahi. Plants in the control seedling were not treated with urea while the other seedlings were treated with urea $(80 \mathrm{~kg} / \mathrm{ha})$ after 40 days of germination. Stem and leaf of paddy were collected from the cultivation field during the summer season and kept in refrigerator.

\section{Preparation of the crude extract of paddy plant}

$165 \mathrm{~g}$ of tissue from control plant crushed in a mortar with pestle were suspended in 50 $\mathrm{mL}$ of ice-cool distilled water. After occasional gentle stirring for 3 hours at $4^{\circ} \mathrm{C}$, the suspension was filtered through double layer of muslin cloth. The filtrate was collected and centrifuged at $8000 \mathrm{RPM}$ for 15 minutes at $4^{\circ} \mathrm{C}$. The supernatant was used as crude extract. For urea treated plant, crude extract was obtained from $185 \mathrm{~g}$ of paddy tissue. The homogenized tissues from control and urea treated paddy were dissolved with another $500 \mathrm{~mL}$ ice cooled distilled water separately.

\section{G-50 Chromatography}

Extracts of urea-treated and control plant were saturated with $80 \%$ ammonium sulfate. The precipitated protein was dialyzed, centrifuged and applied to G-50 collumn preequilibriated with $10 \mathrm{mM}$ phosphate buffer $(\mathrm{pH} 7.2)$ and eluted with the same buffer. Major three fractions F-1, F-2 and F-3 (Fig. 1) were obtained. Aliquotes from the F-1 fraction were used for SDS-PAGE for separation of the urea transporter.

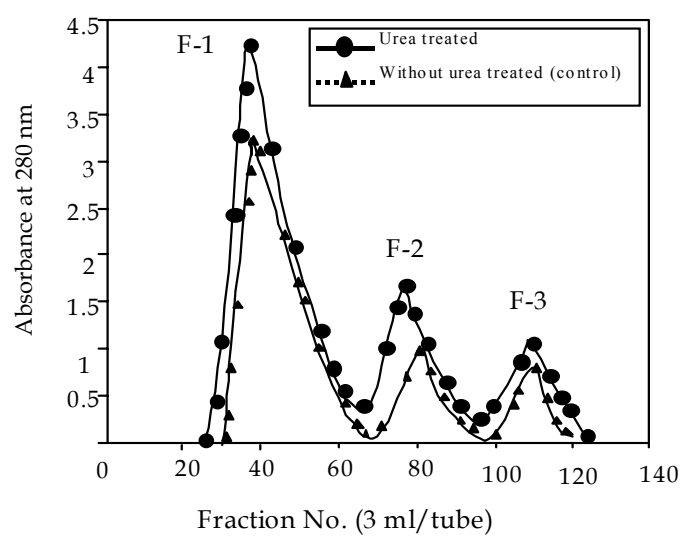

Fig. 1. Gel filtration (G-50) of the extract of paddy. The chromatogram was prepared by plotting the absorbance at $280 \mathrm{~nm}$ against the number of fractions for both the control and urea induced paddy 


\section{SDS-PAGE method for purification of urea transporter}

$100 \mu \mathrm{L}$ of the protein sample mixed with $100 \mu \mathrm{L}$ of sample buffer (4\% SDS, glycerol, 0.5 $\mathrm{M}$ Tris- $\mathrm{HCl}$ buffer, $\mathrm{pH} 6.8$ ), heated for 2-3 minutes in water bath at $100{ }^{\circ} \mathrm{C}$ and one drop of Bromophenol Blue (bromophenol Blue, glycerine, $0.5 \mathrm{M}$ Tris- $\mathrm{HCl}$ buffer) was added. Two types of gels were used. Running gel was prepared by mixing $30 \%$ acryl amide solution (3.4 mL), 1.5M Tris-HCl buffer, $\mathrm{pH} 8.8$ (3.75 mL), de-ionized water $(7.55 \mathrm{~mL})$, $10 \%$ SDS solution $(150 \mu \mathrm{l})$, TEMED $(15 \mu \mathrm{l})$, commercially available from Sigma Chemicals Co., USA, $10 \%$ APS solution $(150 \mu \mathrm{l})$. The flask containing running gel was kept in an ice bath. The gel solution was applied to the sandwich. The top of the gel was covered slowly with a layer of water. It was then allowed to polymerize the gel solution for about one hour at room temperature.

The stacking gel having 30\% acryl amide solution $(1.1 \mathrm{~mL}), 0.5 \mathrm{M}$ Tris-HCl buffer, $\mathrm{pH} 6.8$ $(2.5 \mathrm{~mL})$, de-ionized water $(6.2 \mathrm{~mL}), 10 \%$ SDS solution $(100 \mu \mathrm{L})$, TEMED $(10 \mu \mathrm{L}), 10 \%$ ammonium per sulphate (APS) solution $(100 \mu \mathrm{L})$ was poured on the separating gel in clean and dry plate $(7 \mathrm{~cm} \times 10 \mathrm{~cm})$ with thickness $(1.5 \mathrm{~cm})$. Teflon comb was inserted immediately into the layer of the stacking gel solution. The gel solution was allowed to polymerize for about 30 minutes. The Teflon comb was carefully removed without tearing the edges of the poly-acryl amide wells. The upper buffer chamber was partially filled with the electrophoresis buffer containing $9.09 \mathrm{~g}$ tris base, $43.2 \mathrm{~g}$ glycine and $3 \mathrm{~g}$ SDS so that the top of the gel sandwich was sunk into the electrophoresis buffer. $25 \mu \mathrm{L}$ of protein sample prepared for SDS-PAGE were applied to wells. The gel after electrophoresis was stained with Coomassie Brilliant Blue (CBB) for two hours at room temperature and de-stained with de-staining solution.

\section{Molecular weight determination by SDS-PAGE method}

The molecular weight of urea transporter was determined by comparing the mobility of different marker proteins in the gel. Marker protein was prepared by mixing- $\beta$ galactosidase (MW-116 kDa), BSA (MW-67 kDa), Egg white albumin (MW-45 kDa), Pepsin (MW-36 kDa), Trypsin inhibitor (MW-20 kDa) and Lysozyme (MW-14 kDa) with equal volume of sample solution. The mixture was heated for 2 minutes and then added $3 / 4$ drop of CBB. $20 \mu$ l of protein mixture and sample were carefully applied at the bottom of the different wells. The remainder of the upper buffer chamber was filled with electrophoresis buffer and was continued for electrophoresis. After electrophoresis, the gel was stained and removed the additional dye with de-staining solution.

\section{RESULTS AND DISCUSSION}

\section{Determination of total protein after gel-filtration chromatography}

After gel filtration, different fractions were collected in order to take optical density at $280 \mathrm{~nm}$. In case of urea treated paddy, the protein content was $8 \mathrm{mg} / \mathrm{dl}$ as revealed from F-1 fraction. Where as F-2 fraction and F-3 fraction contained 5 and $3 \mathrm{mg} / \mathrm{dL}$ respectively. However in control (without urea treatment) the protein content was found to be 5,2 and $0.956 \mathrm{mg} / \mathrm{dL}$ in F-1, F-2 and F-3 fractions respectively. The total protein concentrations in two groups were different. However, the total protein concentration for urea treated paddy was higher than the control group. 


\section{Determination of molecular weight by SDS-PAGE method}

The molecular weight of the purified urea transporter from paddy plant extract was determined by sodium dodecyl sulfate polyacrylamide gel electrophoresis (SDS-PAGE) according to Laemmli (Laemmli, 1970). $\beta$-galactosidase (MW-116 kDa), BSA (MW-67 kDa), Egg white albumin (MW-45 kDa), Pepsin (MW-36 kDa), Trypsin inhibitor (MW-20 $\mathrm{kDa})$, Lysozyme (MW-14kDa) were used as molecular weight markers. The standard curve of these proteins was constructed by plotting the molecular weight of the proteins against their mobility on the gel (Fig. 3). For urea exposed extract, significant and separate band was obtained (Shown in Fig. 2) and was expected to be urea transporter compared to the molecular weight of BSA. The molecular weight of urea transporter was found to be $50.6 \mathrm{kDa}$ and migrated as a single band.

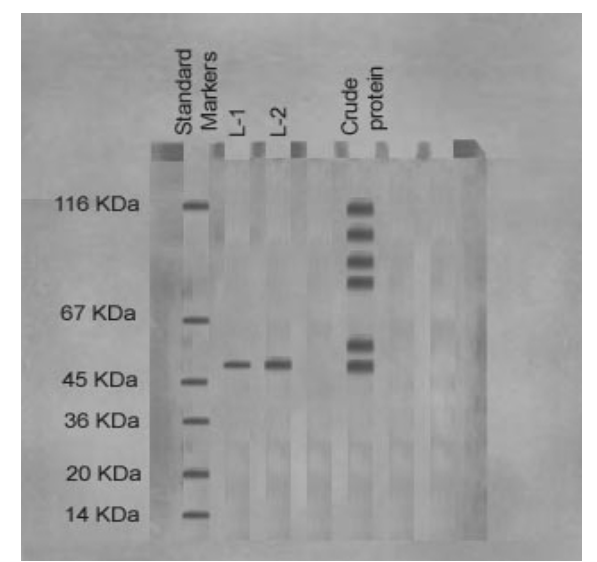

Fig. 2. Photographic representation of SDS-PAGE pattern of the purified protein for determination of molecular weight. Control and urea treated samples were applied to the Lane-1 (L-1) and and Lane-2 (L-2) of the gel respectively.

L-1 : Fraction of without urea treated paddy from gel filtration chromatography; L-2: Fraction of urea treated paddy from gel filtration chromatography; The protein solution containing $\beta$-galactosidase from E. Coli (MW $116 \mathrm{kDa}$ ), BSA (MW $67 \mathrm{kDa}$ ), Egg white albumin (MW $45 \mathrm{kDa}$ ), Pepsin (MW $36 \mathrm{kDa}$ ), Trypsin inhibitor (MW 20 $\mathrm{kDa}$ ) and Lysozyme (MW $14 \mathrm{kDa}$ ) is used as the standard marker.

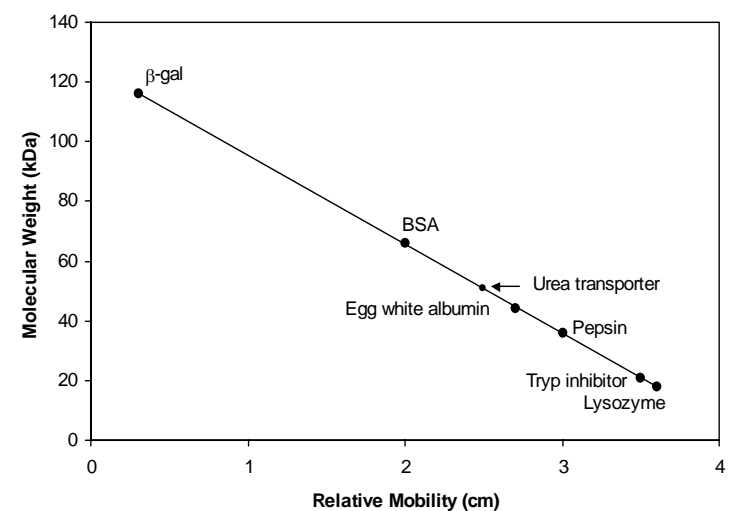

Fig. 3. Molecular weight determination by SDS-PAGE. Molecular weights of $\beta$-galactosidase, BSA, Egg white albumin, pepsin, Trypsin inhibitor and lysozyme are shown as standard protein marker for identification of urea transporter 


\section{Homogeneity of urea transporter}

The homogeneity of urea transporter of F-1 obtained on gel filtration chromatography was judged by SDS-PAGE. The fraction F-1 may contain pure urea transporter as it gives single band on polyacrylamide gel (Fig. 4).

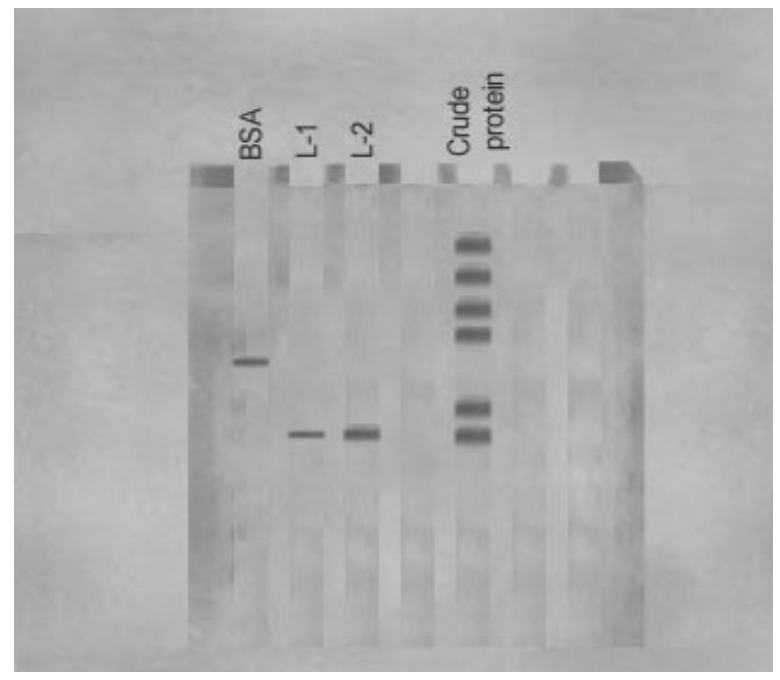

Fig. 4. Photographic representation of sodium SDS-PAGE patteren of the purified protein showing homogeneity of urea transporter. Control and urea treated samples were applied to the Lane-1 (L-1) and and Lane-2 (L-2) of the gel respectively.

L-1 : Fraction of without urea treated paddy from gel filtration chromatography.

L-2: Fraction of urea treated paddy from gel filtration chromatography.

As gel filtration of crude extract treated with urea and control after removal of ammonium sulphate by dialysis, produced major three peaks, the first fraction F-1 contained the higher molecules, was considered for the purification of urea transporter.

Although urea is a commonly used $\mathrm{N}$ form in agricultural plant production, utilization of urea into the plant is not clarified properly. The uptake of urea has been reviewed by some investigators and they concluded that it enters plants and is hydrolysed by urease within cells (Marschner, 1995; Walker et al., 1993.). Therefore, it can be speculated that urea can be utilized through the specific transporter system in plants. In this study, we identified the urea transporter in the extract of paddy plant treated-with and without urea. Application of urea stimulates the expression of transporter as identified by SDSPAGE method (Fig. 2). The approximate molecular weight of urea transporter is $50.6 \mathrm{kDa}$ when compared to the marker proteins. Investigations on the molecular nature of urea transport in human or animal cells have shown that urea is mainly transported through facilitative urea transporters of the UT-A and UT-B families (Smith and Rousselet, 2001; Sands, 2003). UT transporters allow a faster equilibration of urea gradients across cell membranes than would be achieved by passive diffusion alone. Western blot analysis shows that rat heart expresses three UT-A proteins with molecular mass of 56, 51, and 39 
$\mathrm{kDa}$ (Duchesne et al., 2001). UT-B protein appears as a broad band between 45 and 65 $\mathrm{kDa}$ in human red blood cells and 37 to $51 \mathrm{kDa}$ in rat or mouse red blood cells (Yang et al., 2002; Timmer et al., 2001). Therefore, the molecular weight of urea transporter in paddy plant was closely related to their findings. After separation of proteins from the extract, the homogenous bands in the gel for both control and urea-treated paddy respectively were observed. The results suggest that urea transporter is a homogenous protein.

The identification of urea transporter is an important aspect of knowledge for the clarification of the mechanism of urea-induced growth of paddy. It might be expected that application of urea in the soil induces urea transporter activity because of the higher expression in the gel. It could be involved in the regulation of nitrate-induced nitrate transporter for the utilization of amino nitrogen from urea to the plants. Recent investigation reveals that foliar application of urea increases the activity of urease in leaf and stem of paddy (El-Shora, 2001.). It is substantial to purify the urea transporter in paddy after foliar application which will be a useful finding for further characterization of urea transporter.

\section{ACKNOWLEDGEMENT}

We thank Dr. Md. Ansar Ali, Chief Scientific Officer and head, Bangladesh Rice Research Institute, Regional Station, Sympur, Rajshahi for providing us seeds of BRRI-27. The work was supported by the University Grant Commission (UGC), Bangladesh.

\section{REFERENCES}

Claus-Peter, W., Sarah, A. T., Mark, A. T. and Howard, V. D. 2002. Leaf Urea Metabolism in Potato. Urease Activity Profile and Patterns of Recovery and Distribution of ${ }^{15} \mathrm{~N}$ after Foliar Urea Application in Wild-Type and Urease-Antisense Transgenics. Plant Physiol., 128 : 1129-1136.

Crawford, N. M. and Glass, A. D. M. 1998. Molecular and physiological aspects of nitrate uptake in plants. Trends in Plant Science., 3 : 389-395.

Duchesne, R., Klein, J. D., Velotta, J. B. and Doran, J. J. Rouillard, P. 2001. UT-A urea transporter protein in heart: increased abundance during uremia, hypertension, and heart failure. Circ. Res., 89 : 139- 45.

El-Shora, H. M. 2001. Properties and immobilization of urease from leaves of Chenopodium album

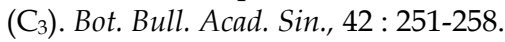

Huang, N. C., Chiang, C. S., Crawford, N. M. and Tsay, Y. F. 1996. CHL1 encodes a component of the low-affinity nitrate uptake system in Arabidopsis and shows cell type-specific expression in roots. Plant Cell., $8: 2183-2191$.

Laemmli, U. K. 1970. Cleavage of structural proteins during the assembly of the head of bacteriophage $\mathrm{T}_{4}$. Nature., $227: 680$.

Lejay, L., Tillard, P., Lepetit, M., Olive, F. D., Filleur, S., Daniel-Vedele, F. and Gojon, A. 1999. Molecular and functional regulation of two uptake systems by $\mathrm{N}$ - and C-status of Arabidopsis plants. The Plant Journal., 18 : 509-519.

Marschner, H. 1995. Mineral nutrition of higher plants. San Diego, Academic Press Limited. 
Sands, J. M. 2003. Mammalian urea transporters. Annu Rev Physiol., 65 : 543-566.

Smith, C. P. and Rousselet, G. 2001. Facilitative urea transporters. J. Membr. Biol., 183 : 1-14

Tsay, Y. F., Schroeder, J. I., Feldmann, K. A. and Crawford, N. M. 1993. The herbicide sensitivity gene CHL1 of Arabidopsis encodes a nitrate-inducible nitrate transporter. Cell., 72 : 705-713.

Timmer, R. T., Klein, J. D., Bagnasco, S. M., Doran, J. J. and Verlander, J. W. 2001. Localization of the urea transporter UT-B protein in human and rat erythrocytes and tissues. Am. J. Physiol. Cell Physiol., 281 : C1318- C25.

von Wiren, N., Lauter, F. R., Ninemann, O., Gillissen, B., Walch-Lui, P., Engels, C., Jost, W. and Frommer, W. B. 2000. Differential regulation of three functional ammonium transporter genes by nitrogen in root hairs and by light in leaves of tomato. The Plant Journal, 21 : 167-175.

Walker, N. A., Reid, R. J. and Smith, F. A. 1993. The uptake and metabolism of urea by Chara australis. 4. Symport with sodium - a slip model for the high and low affinity systems. J. Membran. Biol., 136 : 263-271.

Yang, B., Bankir, L., Gillespie, A., Epstein, C. J. and Verkman, A. S. 2002. Urea-selective concentrating defect in transgenic mice lacking urea transporter UT-B. J. Biol. Chem., 277 : 10633- 37 . 